\title{
ЗОВНІШНС НЕЗАЛЕЖНЕ ОЦІНЮВАННЯ ТА НАЦІОНАЛЬНІ МЕНШИНИ ЗАКАРПАТТЯ
}

\author{
Лесь БЕЛЕЙ \\ кандидат філологічних наук, \\ науковий співробітник Відділу мов України \\ Інститут мовознавства ім. О.О. Потебні НАН України \\ to.mamay@gmail.com1 \\ https://orcid.org/0000-0003-4094-6418
}

DOI 10.25128/2304-1222.20.51.06

\begin{abstract}
The article is devoted to the analysis of the level of education of the Romanian and Hungarian national minorities of Zakarpattia oblast of Ukraine. The results of the External independent evaluation in Ukrainain language and literature (2016 - 2020), history of Ukraine, Mathematics, physics, chemistry, biology (2020), the percentage of failed EIE and average results were analyzed. The results of the national minority representatives were compared with the results of the Ukrainian graduates in order to test the equality of the chances for higher education.
\end{abstract}

Key words: EIE, Ukrainian language, national minorities, Hungarians, Romanians.

У статті проаналізовано рівень освіти представників угорської та румунської меншини Закарпаття. Зіставлено результати зовнішнього незалежного оцінювання з української мови та літератури (протягом 2016 - 2020 рр.), історії України, математики, фізики, хімії, біології (2020р.), зокрема відсоток нескладених іспитів та середній бал. Показники представників національних меншин порівнюються з показниками українських школярів для оцінки рівності можливостей під час вступу до вищих навчальних закладів та потенціалу реалізації права на освіту.

Ключові слова: ЗНО, українська мова, національні меншини, угорці, румуни.

Artykuł jest poświęcony analizie poziomu edukacji w rumuńskiej oraz węgierskiej mniejszości narodowej w Zakarpackim obwodzie Ukrainy. Badanie jest oparte na porównaniu wyników Zewnętrznego niezależnego oceniania (ZNO) z ukraińskiego języka i literatury (2016 - 2020), historii Ukrainy, matematyki, fizyki, chemii, biologii (2020), z uwzględnieniem odsetku ocen niedostatecznych i średnich. Wyniki przedstawicieli mniejszości narodowych w badaniu są porównywane z wynikami Ukraińców etnicznych w celu oceny równości szans na wykształcenie wyższe oraz możliwości realizacji prawa do edukacji.

Słowa kluczowe: ZNO, język ukraiński, mniejszości narodowe, Węgry, Rumuni.

Серед основних прав національних меншин - право на освіту. I саме воно вирізняється тим, що, з одного боку, представники національних меншин повинні зберігати та удосконалювати свою рідну мову під час освітнього процесу, а з іншого - вони мають успішно інтегруватися в український соціум.

Протягом перших 15 років незалежності проблема віднайдення балансу між цими двома векторами не була видимою. Ситуація кардинально змінилася після запровадження зовнішнього незалежного оцінювання у 2007 р. (наказ № 1171 від 25 грудня). 3 цього часу уніфікований екзамен з української мови та літератури став обов'язковим для вступу на будьякі спеціальності українських ВНЗ. 
Виявилося, що програми навчання української у школах національних меншин недостатні, і випускники отримують дуже низькі бали на ЗНО. Особливо гостро ця проблема постала серед представників угорської та румунської меншин, що компактно проживають у Закарпатській та Чернівецькій областях. Їхні спільноти доволі ізольовані, тому зі знаннями української виникають труднощі, а курси вивчення державної мови у школах не справляються 3 місією інтеграції випускників в українське суспільство.

Коли українська влада вирішила удосконалити освіту для національних меншин у 2017 р. [див. Закон України Про освіту], здійнялася хвиля протесту з Угорщини та Румунії [див. Будапешт і Бухарест], бо там побоювалися асиміляції угорців та румунів України.

Проблема освіти для національних меншин у сучасній Україні привернула увагу дослідників. Дехто звертає увагу на недосконалість української освіти для національних меншин див. С. Черничко [2018], А. Барань, С Барань [2016], дехто вказує на безпідставність претензій угорського уряду див. В. Коцур [2018]. Так чи інакше, українські урядовці визнають проблему з освітою для національних меншин, тому протягом останніх років ситуація почала змінюватися. Ми проаналізуємо результати ЗНО 2016-2020 рр. у місцях компактного проживання угорської та румунської національних меншин, щоб оцінити особливості реалізації права на освіту та потенціал інтегрування представників національних меншин у соціум. Ці дані викладені у вільний доступ на сторінці Українського центру оцінювання якості освіти.

Угорська меншина компактно проживає на півдні Закарпатської області. За переписом 2001 р. в області жило 151,5 тис. угорців. Це 12 \% всього населення. 3 них 95 \% назвали угорську рідною. Серед угорців переважає сільське населення (63,8%). Міське концентрується у Берегові (48,1 \% угорців). Існують села, у яких майже усі мешканці угорськомовні: Гетен (98,6 \%), Мала Добронь (98,5%), Тисааглетек (98,4%). Понад 90 \% угорськомовних зафіксовано ще у 41 селі. У 19 селах - 80 - 90 \% угорськомовних, у 13 селах $60-80 \%$ [див. Результати перепису населення].

Румунськомовна меншина Закарпаття значно менша - 32 тис. (преважна більшість мешкає на Буковині 115 тис.) Конценруються вони на півдні Тячівського та Рахівського районів. Як і угорці, румуни живуть у компактних однорідних, переважно сільських спільнотах. У селах Пещера, Топчино, Середнє Водяне, Глибокий Потік, Добрік, Нижня Апша, Біла Церква, Подішор від 90 до 100 \% румунськомовних [там же].

На Схемі 1 подано статистику провалу 3НО з української мови та літератури за 2016 2020 р. у Берегівському (76 \% угорців) та Хустському (95 \% українців) районах (до адміністративної реформи). На Схемі 2 зіставлено середній бал за цю дисципліну у двох районах. 
Схема 1

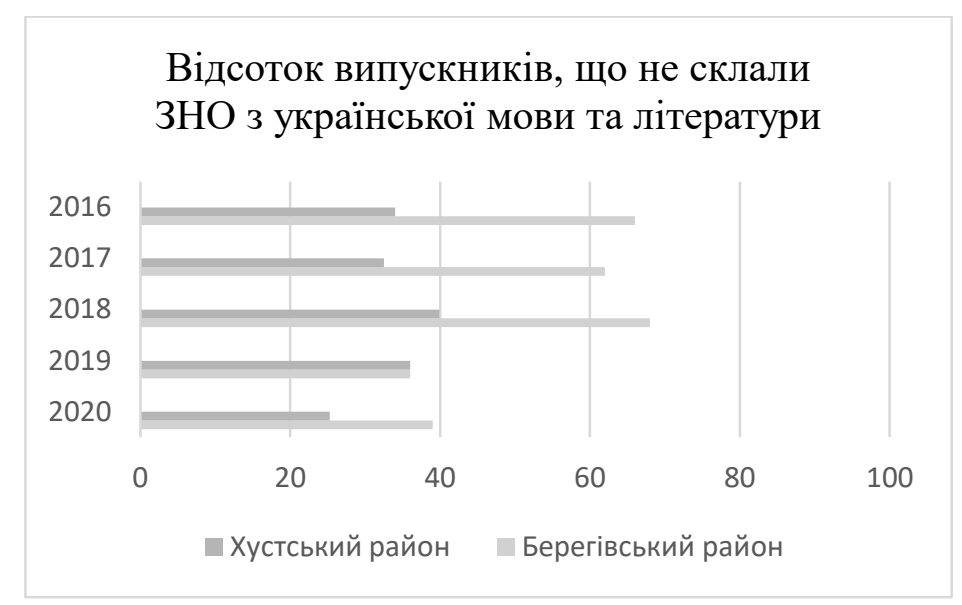

Схема 2

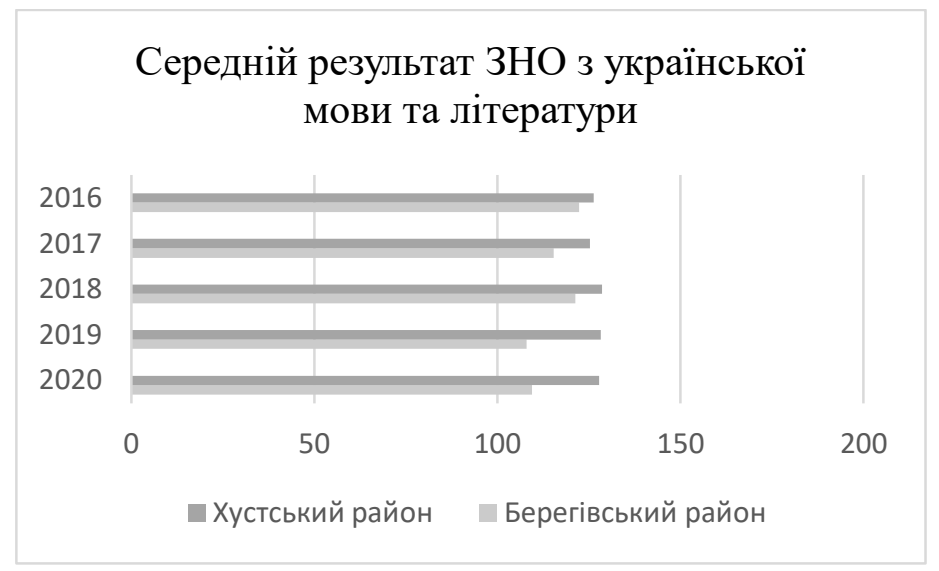

У 2016-2018 рр. в угорській меншині були найпровальніші результати ЗНО з української мови та літератури. У 2018 р. 68 \% випускників Берегівського району не склали цей іспит. Однак серед тих, хто подолали 100 бальний бар'єр, середній показник не сильно відрізнявся від Хустського району. У 2019 р. для шкіл з навчанням мовами національних меншин увели окрему шкалу оцінювання. На загальноукраїнскьому рівні був встановлений пороговий бал 23 (= 100 балів), а для представників нацменшин він склав 14 балів (=100 балів) (на 38 \% менший) [див. ЗНО 2019]. У цей рік відсоток нескладеного ЗНО з української мови та літератури у Берегівському та Хустському районах був однаковий (36\%). У 2020 році різниця між пороговими балами була меншою (22 і 15), тому Берегівський район знову почав відставати. Через те, що за останні два роки у Берегівському районі більше випускників зі слабкими знаннями подолали поріг, знизився середній бал.

На Схемах 4 і 5 зіставлено відсоток випускників, що успішно подолали 100 бальний бар’єр та середній бал серед закарпатських українців, угорців, румунів та румунів Буковини. 


\section{Схема 3}

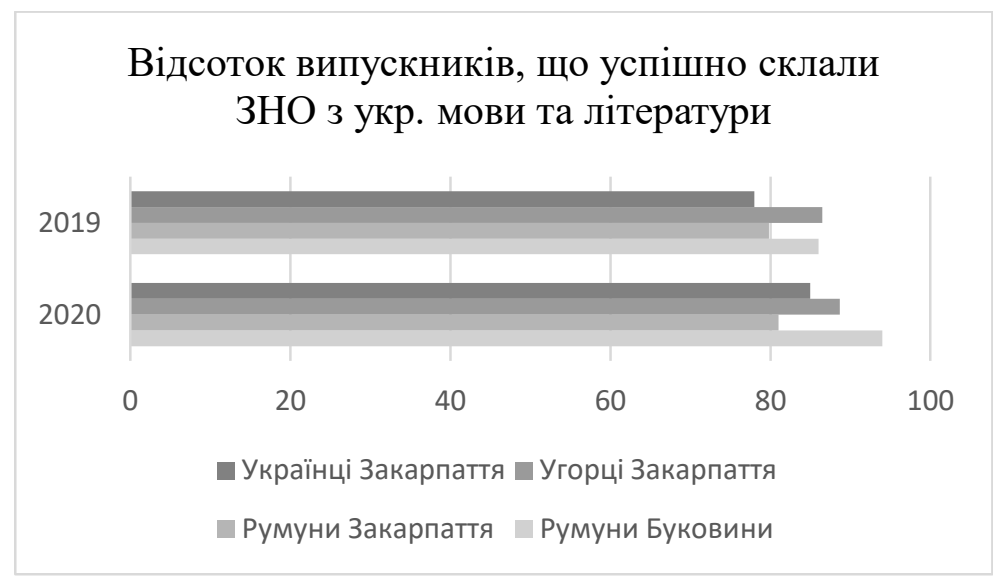

Схема 4

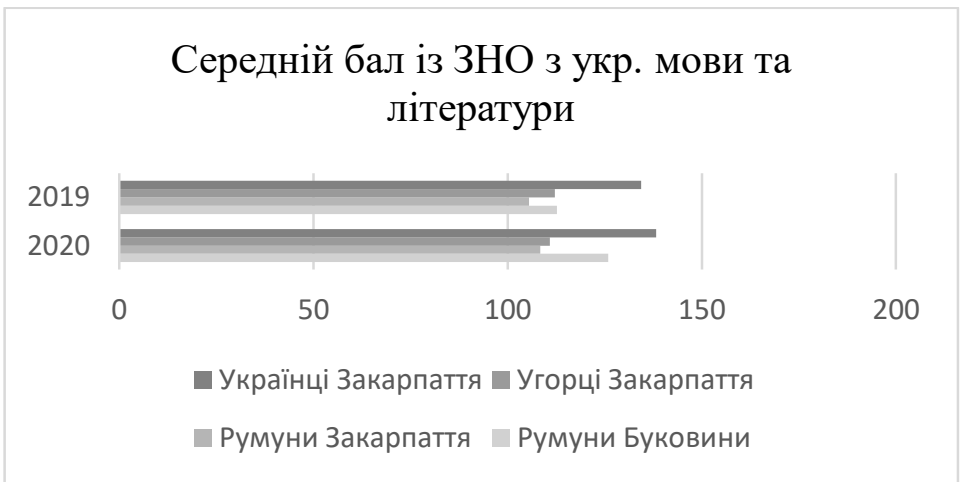

Як бачимо, адаптивне оцінювання дало свої результати у 2019 році більше представників нацменшин успішно склали ЗНО української мови та літератури, ніж українців, у 2020 р. закарпатські румуни показали гірший результат, ніж закарпатські українці. Однак, якщо взяти до уваги середній бал, то тут українці суттєво випереджають національні меншини. Буковинські румуни показують кращі результати, ніж закарпатські, що свідчить про вищий рівень тамтешньої освіти.

Якщо поглянути на результати населених пунктів, де найвища концентрація представників національних меншин, то там результати доволі погані.

У Малій Доброні, Варах, Дерцені, Косоні (де більше 90 \% угорськомовних), середній бал ЗНО з української мови та літератури на межі провалу - 100-103 балів (з 200). У переважно румунськомовному селі Біла Церква середній бал - 107,6.

Представники угорської нацменшини, що проживають у містах, успішніше складають ЗНО з української мови та літератури, ніж селяни. Середній бал містян у 2020 р. - 114,5, а в селах $-107,4$.

У схемі 5 подано середній бал з інших популярних дисциплін ЗНО. 


\section{Схема 5}

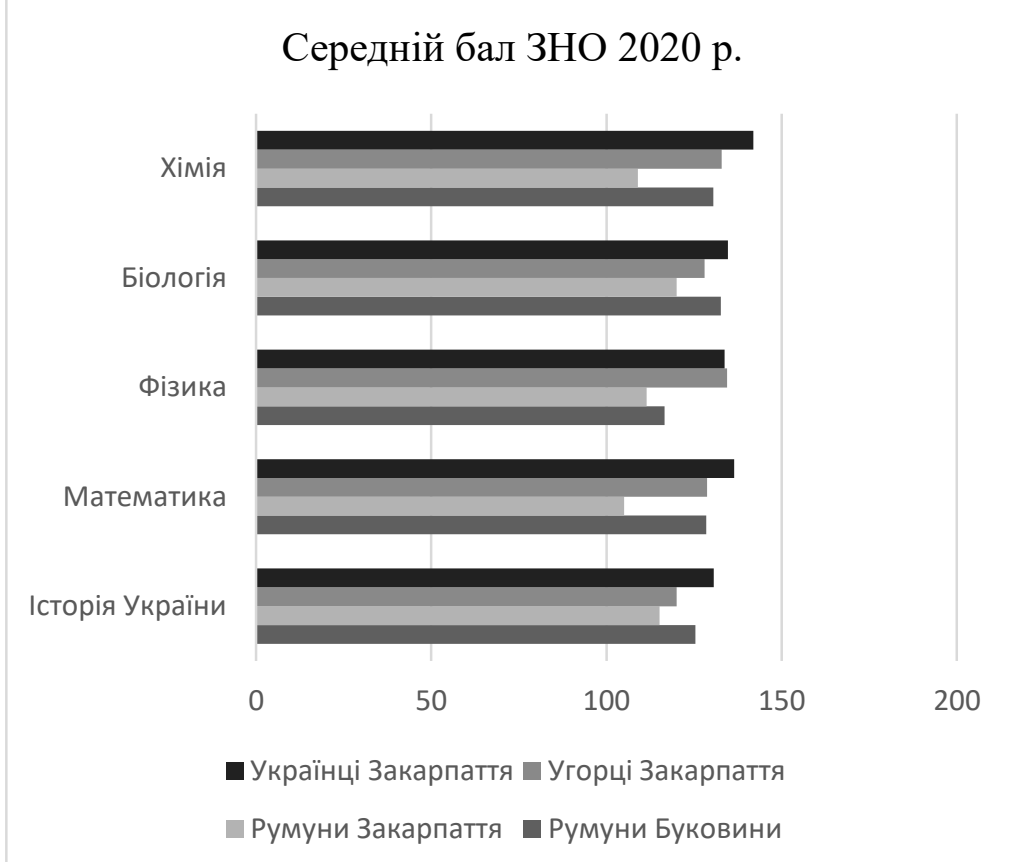

Інші дисципліни, окрім української мови та літератури представники нацменшин складають своїми мовами, тому результати мало відрізняються від українців. Як бачимо, закарпатські румуни мають суттєво нижчий рівень знань, ніж буковинські.

Проведений аналіз показав, що протягом 2019 - 2020 р. вдалося подолати проблему провального складання ЗНО з української мови та літератури представниками національних меншин. Адаптивний поріг майже вирівняв результати. Однак навіть 3 таким спрощенням середній бал за ЗНО українських угорців та румунів залишається усе ще суттєво нижчим, ніж у випускників шкіл з українською мовою навчання. Це створює суттєві перешкоди при вступі в університети, оскільки представники національних меншин мають значно менше балів, ніж українці.

Окрім того, зважаючи на те, що ЗНО з інших предметів представники національних меншин складають своїми мовами, у них виникають суттєві труднощі у ВНЗ, де навчання ведеться українською.

Таким чином програма вивчення української для національних меншин потребує радикального реформування. Окрім того, якість освіти у селах поступається рівнем міській, це доводять результати ЗНО. Рівень освіти закарпатських румунів у гіршому стані, ніж в угорців.

За прикінцевими положеннями Закону України «Про освіту» 2017 р. «особи, які належать до національних меншин України, мови яких є офіційними мовами Європейського Союзу, i розпочали здобуття загальної середньої освіти до 1 вересня 2018 року мовою відповідної національної меншини, до 1 вересня 2023 року продовжують здобувати таку освіту відповідно до правил, які існували до набрання чинності цим Законом, з поступовим збільшенням кількості навчальних предметів, що вивчаються українською мовою» [див. Прийнято новий закон]. 
У «Законі про повну загальну середню освіту», ухваленому у 2020 р. для нацменшин, мови яких належать до мов СС, так змодельовано систему освіти: «материнською мовою, поряд 3 вивченням державної, вони навчатимуться у початковий школі; у 5 класі не менше 20\% річного обсягу навчального часу має викладатись українською з поступовим збільшенням обсягу, щоб у 9 класі досягти позначки у не менше 40\% предметів, які вивчаються державною мовою; зі старшої школи не менше $60 \%$ річного обсягу навчального часу в цих закладах має читатися державною мовою» [там же].

Отже, коли норми цих законів будуть імплементовані, а програми вивчення української мови та літератури адаптовані до сучасних вимог, ситуація з інтеграцією представників національних меншин в українське суспільство має покращитися.

\section{ЛІТЕРАТУРА}

Барань, А., Барань, Є. Засоби покращення результатів ЗНО з української мови та літератури серед учнів шкіл Закарпаття з угорською мовою навчання. «Теорія і практика викладання української мови як іноземної». 2016. Вип. 12. 248-256 [Baran', А., Baran', Ye. Zasobi pokrashchennya rezul'tativ ZNO z ukrayins'koyi movi ta literaturi sered uchniv shkil Zakarpattya z uhors'koyu movoyu navchannya. “Teoria i praktika vikladannya ukrayins'koyi movi yak inozemnoyi”. 2016. Vip. 12. 248-256].

Будапешт i Бухарест спільно виступили проти українського закону про освіту. URL: https://ua.interfax.com.ua/news/political/452429.html (10.11.2020) [Budapesht i Bukharest spil'no vistupili proti ukrayins'koho zakonu pro osvitu].

Закон України Про освіту. URL: https://zakon.rada.gov.ua/laws/show/2145-19\#Text (10.11.2020) [Zakon Ukrayini Pro osvitu].

ЗНО 2019 - результати Закарпаття з української мови та літератури. URL: http://kmf.uz.ua/ uk/zno-2019rezultati-zakarpattja-z-ukrain/?fbclid=IwAR0ipjo1L2-zmK1 YFD3Qtm

_eWNQ1bbfZxpkmI8sqTjf86p1lVTSExcHK1_k (10.11.2020) [ZNO 2019 - rezultati Zakarpattya z ukrayins'koyi movi ta literaturi].

Коцур, В. Угорська національна меншина у поліетнічному просторі України ХХІ століття: мовний чинник. «Науковий вісник Ужгородського національного університету. Серія Міжнародні відносини». 2018. Вип. 3. 45-52 [Kotsur, V. Uhors 'ka natsional'na menshina u polietnichnomu prostori Ukrayini XXI stolittya: movniy chinnik. „Naukoviy visnik Uzhhorods'koho natsional'noho universitetu. Seriya Mizhnarodni vidnosini”. 2018. Vip. 3. 42-52].

Прийнято новий закон “Про повну загальну середню освіту”. URL: https://mon.gov.ua/ua/news/prijnyatonovij-zakon-pro-povnu-zagalnu-serednyu-osvitu-za-progolosuvali-450nardepiv?fbclid=IwAR3HFkWFvmGTSi4A-qOUXrPcwrjgisVBefiFI98dBpdDZJNFckkBcd-d5WE (дата звернення: 10.11.2020) [Priynyato noviy zakon "Pro povnu zahal'nu serednyu osvitu"].

Результати перепису населення. URL: http://2001.ukrcensus.gov.ua/results/nationality_ population/nationality_popul1/ (10.11.2020) [Rezul'tati perepisu naselennya].

Черничко, С. Державна мова для угориів Закарпаття: чинник інтеграиії, сегрегаиії чи асиміляиії? «Стратегічні пріоритети». 2018. №1. 97-105. URL: https://zno.testportal.com.ua/opendata (10.11.2020) [Chernichko, S. Derzhavna mova dla uhortsiv Zakarpattya: chinnik intehratsiyi, sehrehatsiyi chi asimilatsiyi? "Stratehichni prioriteti". 2018. No 1.97-105]. 